\title{
Integrated Approach Using Remote Sensing and GIS for Assessment of Groundwater Quality and Hydrogeomorphology in Certain Parts of Tummalapalle Area, Cuddapah District, Andhra Pradesh, South India
}

\author{
Arveti Nagaraju ${ }^{1}$, Yenamala Sreedhar ${ }^{1}$, Arveti Thejaswi ${ }^{2}$, Padmanava Dash ${ }^{3}$ \\ ${ }^{1}$ Department of Geology, Sri Venkateswara University, Tirupati, India \\ ${ }^{2}$ Environmental Sciences, School of Distance Education, Kakatiya University, Warangal, India \\ ${ }^{3}$ Mississippi State University, Mississippi State, MS, USA \\ Email: *arveti9@gmail.com
}

Received 22 February 2016; accepted 3 June 2016; published 6 June 2016

Copyright (C) 2016 by authors and Scientific Research Publishing Inc.

This work is licensed under the Creative Commons Attribution International License (CC BY). http://creativecommons.org/licenses/by/4.0/

(c) (i) Open Access

\begin{abstract}
The present work deals with the assessment of groundwater potential zones and their suitability for drinking in the severely drought affected villages of Vemula mandal of Cuddapah District, Andhra Pradesh. This study is based on remote sensing and GIS approach. In this approach the IRS P6 LISS III Data (23.5 m Spatial Resolution) with Path: 100; Row: 063 of Indian Remote Sensing Satellite, Resourcesat IRS-P6 LISS-III has been utilized to analyse the onscreen interpretation and delineated different geomorphological units, lithological formations and geological structures. By integrating the above said parameters the hydrogeomorphological map is prepared on 1:50,000 scale. The study area is characteristically occupied by the Papaghni and Chitravati group of rocks. In the present study, the lithological formations on the basis of their genesis have been classified as fluvial, denudational and structural. Majority of lineaments are trending in NE-SW and NW-SE directions. The fluvial landforms namely valley fill moderate and valley have good groundwater prospects while shallow weathered buried pediplain has moderate to poor groundwater prospects. The chemical quality parameters of groundwater samples have indicated that the water samples are found to be suitable for drinking, agricultural, and industrial purposes.
\end{abstract}

${ }^{*}$ Corresponding author.

How to cite this paper: Nagaraju, A., et al. (2016) Integrated Approach Using Remote Sensing and GIS for Assessment of Groundwater Quality and Hydrogeomorphology in Certain Parts of Tummalapalle Area, Cuddapah District, Andhra Pradesh, South India. Advances in Remote Sensing, 5, 83-92. http://dx.doi.org/10.4236/ars.2016.52007 


\section{Keywords}

\section{Remote Sensing, GIS, Groundwater, Hydrogeomorphology, Water Quality}

\section{Introduction}

India's water resources are stressed and depleting rapidly in line with urbanization, population increases. In general groundwater prospecting, exploration and management have become a big task in India. Groundwater, which makes up about $20 \%$ of the world's fresh water supply and is about $0.61 \%$ of the entire world's water, including oceans and permanent ice, is an important source of drinking water throughout the world [1]. Groundwater is naturally replenished by surface water from precipitation, streams, and rivers when this recharge reaches the water table [2]. About 95\% of rural population living in India depends on groundwater for domestic use [3]. The drastic increase in population, urbanization and modern land use applications and demands for water supply has limited the globally essential groundwater resources in terms of both its quality and quantity. About 95\% of rural population living in India depends on groundwater for domestic use [4] [5]. Hence, in the current scenario, it has become crucial not only to find groundwater potential zones, but also to monitor and conserve this important natural resource [6].

Sustainability of groundwater dictates that its extraction should be at a rate which does not exceed annual recharge and does not lead to groundwater mining [7]. In recent times, much importance has been given to the environmental quality of water because of its importance in maintaining the human health and health of the ecosystem [8] [9]. The improper management of water systems may cause serious problems in availability and quality of water [10]. Further, the groundwater is used intensively for irrigation and industrial purposes including a variety of land and water based human activities and are causing pollution of this precious resource [11]-[13].

During the past decade, widespread reports of groundwater contamination have increased public concern about drinking water quality. The chemical character of any groundwater determines its quality and utilization. Understanding the quality of groundwater is important as its quality because it is the main factor determining its suitability for domestic, drinking, agricultural and industrial purposes. Water quality depends upon the composition of recharge water, geological constituents and interaction of soil, salt content and several other substances in soluble form within the aquifer. Further, the groundwater regime of any area is largely controlled by parameters like lithology, structures, geomorphology, slope, land use/land pattern etc. These features are inter-related and important for understanding the hydrological set-up of any area [14] [15]. The relevant baseline information on such features can be generated and analyzed as an individual thematic layer in the GIS environment [16] [17]. Subsequently, these thematic layers, generated by using the remote sensing data can be integrated in a GIS framework and further analyzed by using models developed with logical condition to demarcate the different groundwater potential zones [15] [18]. Remote sensing and GIS technology have opened new paths in groundwater studies. The concept of integrated remote sensing and GIS has proved to be an efficient tool in integrating urban planning and ground water studies. In view of this, a study has been undertaken to understand the significance of remote sensing and GIS techniques in hydrogeomorphology and ground water quality of Tummalapalle area, Cuddapah District.

\section{Study Area}

Tummalapalle area is located in Vemula mandal, Cuddapah district, Andhra Pradesh. It is a highly drought affected region and is about $70 \mathrm{~km}$ from the district headquarters. The nearest town is Pulivendla, which is about $15 \mathrm{~km}$ away by road.It is located in the Survey of India Toposheet No: $57 \mathrm{~J} / 3$ and $57 \mathrm{~J} / 7$ on 1:50,000 scale and lies between North latitudes $14^{\circ} 16^{\prime} 00^{\prime \prime}$ to $14^{\circ} 24^{\prime} 00^{\prime \prime}$ and East longitudes $78^{\circ} 13^{\prime} 00^{\prime \prime}$ to $78^{\circ} 23^{\prime} 00^{\prime \prime}$ (Figure 1). The total geographical area of study comprises 112.48 sq.km and covers parts of Vemula, Velpula, Kottalu, Mobbuchintalapalle, Medipentla, Bhumayagaripalle, Rachakuntapalle, Gondipalle, V. Kothapalle villages.

\section{Data Used and Methodology}

In this study we have incorporated three types of data sets and were used for the groundwater assessment studies; 


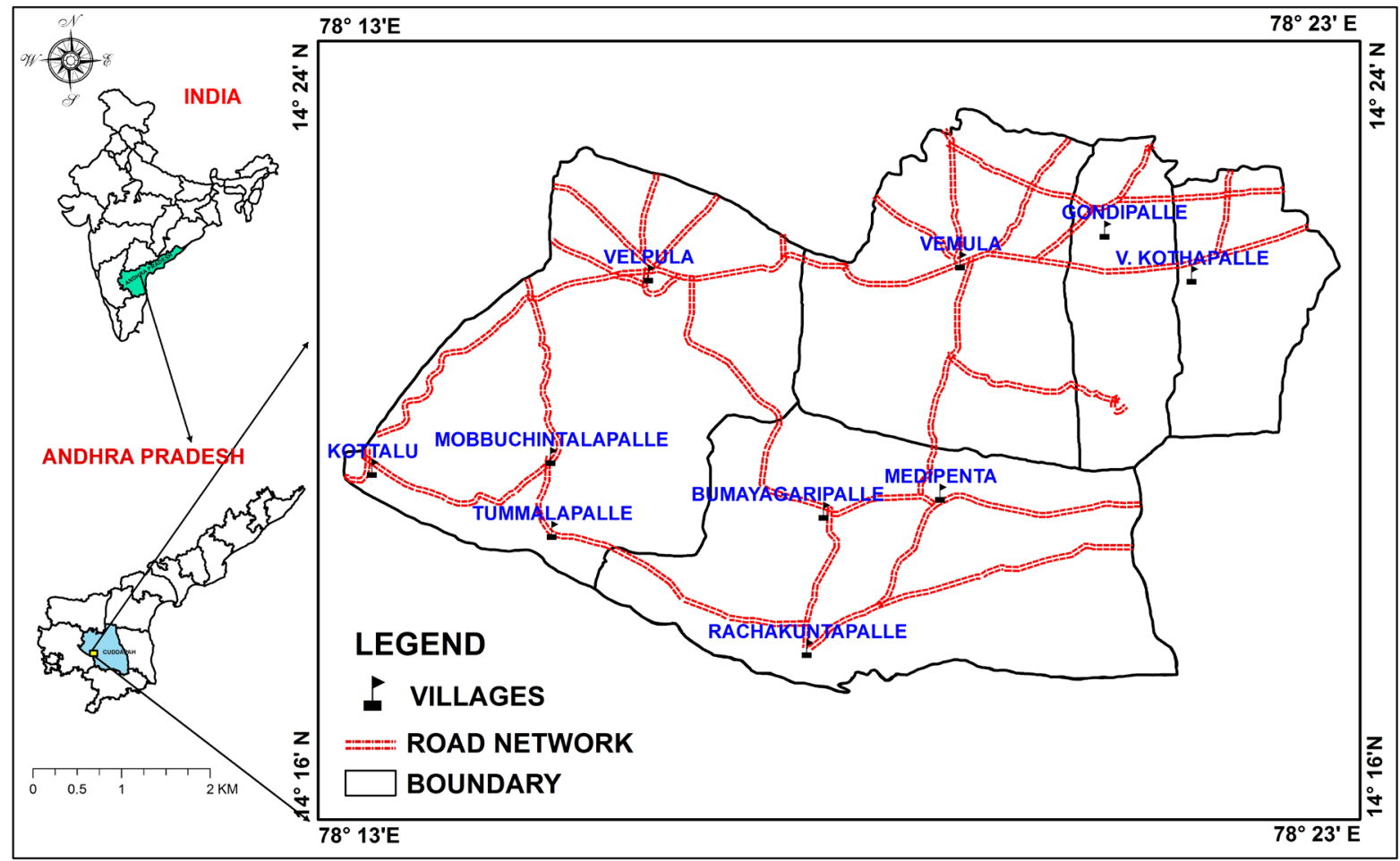

Figure 1. Map of the study area.

a) topographical map (57 J/7) of Survey of India on 1:50,000 scale; b) remotely sensed data viz. IRS-P6-LISS-III data with Path: 100 and Row: 063 having a spatial resolution of $23.5 \mathrm{~m}$ covering Tummalapalle area is analyzed geo-coded on 1:50,000 scale (satellite imagery was taken on $13^{\text {th }}$ February 2012); and c) selected field checks were carried out in the field to verify different geomorphic units. The preprocessing for the satellite image has been geometrically corrected satellite imagery for effective cartographic applications in this study. Onscreen interpretation is carried out delineating different geomorphological units/landforms, lithological formations and geological structures and hydrogeomorphological map is prepared by integrating the above said parameters [19]. Further, well inventory data collected during fieldwork is made use in finalizing hydrogeomorphological/ groundwater prospects map of the study area. The image characteristics like tone, texture, pattern, shape, association, drainage etc. were used to identify different features and their respective units [20]. Accordingly, different thematic maps were prepared and subsequently digitized in the GIS environment with the help of Arc GIS 9.3 software.

About forty groundwater samples are collected in and around Tummalapalle area and are analyzed for various chemical parameters viz., $\mathrm{pH}$, total dissolved solids, Total Hardness, alkalinity, bicarbonate, carbonate, chloride, calcium, magnesium, fluoride, sodium and potassium (Table 1). The techniques and methods followed for collection, preservation, analysis and interpretation are those given by APHA and Todd and Mays [21] [22].

\section{Geology}

The study area is characteristically occupied by the Papaghni and Chitravati group of rocks of Cuddapah Super Group. Papaghni group includes a) Gulcheru formation comprising quartzite, arkose and conglomerate; b) Vempalli formation comprising dolomites, chert, mudstone, quartzite, basic flows and intrusive. The Chitravati group includes a) Pulivendla formation comprising quartzite with conglomerate and b) Tadipatri formation consisting of shales, dolomite and quartzite; c) Gandikota formation comprising quartzite and shale. Lithologically, the Vempalli formation consists of purple shale, massive limestone, intraformational conglomerate, dolostone (uraniferous), shale and cherty limestone. The radioactive minerals identified in the ore zone are pitchblende, coffinite, U-Ti complex [23] [24]. 
Table 1. Chemical analysis of water samples in the study area.

\begin{tabular}{|c|c|c|c|c|c|c|c|c|c|c|c|c|c|c|c|}
\hline $\begin{array}{l}\text { Sl. } \\
\text { No. }\end{array}$ & $\begin{array}{c}\text { Sample } \\
\text { No. }\end{array}$ & $\begin{array}{c}\text { EC } \\
(\mu \text { mhos } / \mathrm{cm})\end{array}$ & $\mathrm{pH}$ & $\begin{array}{c}\mathrm{Ca} \\
(\mathrm{mg} / \mathrm{l})\end{array}$ & $\begin{array}{c}\mathrm{Mg} \\
(\mathrm{mg} / \mathrm{l})\end{array}$ & $\begin{array}{c}\mathrm{Na} \\
(\mathrm{mg} / \mathrm{l})\end{array}$ & $\begin{array}{c}\mathrm{K} \\
(\mathrm{mg} / \mathrm{l})\end{array}$ & $\begin{array}{l}\mathrm{HCO}_{3} \\
(\mathrm{mg} / \mathrm{l})\end{array}$ & $\begin{array}{c}\mathrm{CO}_{3} \\
(\mathrm{mg} / \mathrm{l})\end{array}$ & $\begin{array}{c}\mathrm{Cl} \\
(\mathrm{mg} / \mathrm{l})\end{array}$ & $\begin{array}{c}\mathrm{SO}_{4} \\
(\mathrm{mg} / \mathrm{l})\end{array}$ & $\underset{(\mathrm{mg} / \mathrm{l})}{\mathrm{F}}$ & $\begin{array}{l}\text { TDS } \\
(\mathrm{mg} / \mathrm{l})\end{array}$ & $\begin{array}{c}\text { Hardness } \\
\text { as } \mathrm{CaCO}_{3} \\
(\mathrm{mg} / \mathrm{l})\end{array}$ & $\begin{array}{c}\text { Alkalinity } \\
\text { as } \mathrm{CaCO}_{3} \\
(\mathrm{mg} / \mathrm{l})\end{array}$ \\
\hline 1 & S.N 1 & 2020 & 7.3 & 67 & 84 & 22 & 19 & 349 & 137 & 33 & 22 & 0.28 & 1313 & 372 & 108 \\
\hline 2 & S.N 2 & 2040 & 7.4 & 93 & 35 & 27 & 13 & 262 & 93 & 49 & 12 & 0.45 & 1326 & 160 & 98 \\
\hline 3 & S.N 3 & 2060 & 7.6 & 47 & 42 & 35 & 9 & 222 & 67 & 53 & 9 & 0.32 & 1339 & 188 & 95 \\
\hline 4 & S.N 4 & 2240 & 7.4 & 73 & 55 & 34 & 9 & 289 & 106 & 49 & 9 & 0.42 & 1456 & 244 & 98 \\
\hline 5 & S.N 5 & 2160 & 7.3 & 65 & 85 & 34 & 10 & 356 & 131 & 55 & 10 & 0.52 & 1404 & 376 & 98 \\
\hline 6 & S.N 6 & 1210 & 6.8 & 25 & 75 & 13 & 21 & 251 & 101 & 31 & 9 & 0.11 & 787 & 332 & 36 \\
\hline 7 & S.N 7 & 1530 & 7.1 & 29 & 56 & 15 & 11 & 214 & 74 & 27 & 12 & 0.38 & 995 & 248 & 52 \\
\hline 8 & S.N 8 & 1840 & 7.9 & 73 & 93 & 31 & 2 & 367 & 135 & 65 & 16 & 0.44 & 1196 & 412 & 102 \\
\hline 9 & S.N 9 & 1340 & 7.2 & 45 & 69 & 26 & 5 & 244 & 106 & 53 & 10 & 0.38 & 871 & 308 & 49 \\
\hline 10 & S.N 10 & 2000 & 7.3 & 59 & 73 & 22 & 15 & 306 & 117 & 43 & 8 & 0.42 & 1300 & 324 & 82 \\
\hline 11 & S.N 11 & 1860 & 7.5 & 69 & 55 & 20 & 19 & 267 & 93 & 53 & 15 & 0.36 & 1209 & 244 & 89 \\
\hline 12 & S.N 12 & 1640 & 7.3 & 109 & 108 & 26 & 3 & 435 & 162 & 93 & 18 & 0.56 & 1066 & 480 & 85 \\
\hline 13 & S.N 13 & 1980 & 7.4 & 173 & 133 & 55 & 5 & 509 & 222 & 207 & 28 & 0.38 & 1287 & 596 & 72 \\
\hline 14 & S.N 14 & 2020 & 7.5 & 67 & 100 & 54 & 7 & 390 & 164 & 67 & 19 & 0.25 & 1313 & 444 & 72 \\
\hline 15 & S.N 15 & 1940 & 7.5 & 63 & 81 & 44 & 73 & 389 & 135 & 85 & 16 & 0.34 & 1261 & 360 & 144 \\
\hline 16 & S.N 16 & 2060 & 7.4 & 69 & 72 & 24 & 2 & 308 & 113 & 45 & 18 & 0.28 & 1339 & 320 & 89 \\
\hline 17 & S.N 17 & 1780 & 7.2 & 83 & 49 & 19 & 3 & 277 & 95 & 35 & 19 & 0.42 & 1157 & 220 & 95 \\
\hline 18 & S.N 18 & 1940 & 7.4 & 77 & 76 & 20 & 3 & 294 & 122 & 29 & 65 & 0.37 & 1261 & 340 & 75 \\
\hline 19 & S.N 19 & 2140 & 7.5 & 67 & 72 & 13 & 3 & 229 & 96 & 35 & 94 & 0.27 & 1391 & 320 & 66 \\
\hline 20 & S.N 20 & 1730 & 7.2 & 81 & 49 & 31 & 24 & 294 & 112 & 45 & 10 & 0.48 & 1125 & 220 & 79 \\
\hline 21 & S.N 21 & 2160 & 7.5 & 47 & 39 & 33 & 3 & 193 & 61 & 59 & 8 & 0.30 & 1404 & 172 & 95 \\
\hline 22 & S.N 22 & 1980 & 7.4 & 69 & 35 & 11 & 4 & 199 & 74 & 33 & 10 & 0.44 & 1287 & 156 & 79 \\
\hline 23 & S.N 23 & 1430 & 7.3 & 55 & 43 & 6 & 2 & 183 & 66 & 37 & 16 & 0.40 & 930 & 192 & 66 \\
\hline 24 & S.N 24 & 1980 & 7.5 & 95 & 44 & 13 & 3 & 294 & 101 & 21 & 12 & 0.54 & 1287 & 200 & 85 \\
\hline 25 & S.N 25 & 2060 & 7.3 & 67 & 37 & 48 & 5 & 253 & 87 & 51 & 8 & 0.28 & 1339 & 168 & 102 \\
\hline 26 & S.N 26 & 2120 & 7.2 & 45 & 27 & 51 & 7 & 130 & 38 & 113 & 11 & 0.46 & 1378 & 120 & 82 \\
\hline 27 & S.N 27 & 1850 & 7.1 & 83 & 43 & 43 & 2 & 236 & 72 & 109 & 12 & 0.28 & 1203 & 192 & 98 \\
\hline 28 & S.N 28 & 1780 & 7.2 & 95 & 63 & 75 & 22 & 320 & 120 & 151 & 10 & 0.62 & 1157 & 280 & 89 \\
\hline 29 & S.N 29 & 2150 & 7.5 & 69 & 45 & 30 & 2 & 254 & 93 & 37 & 8 & 0.54 & 1398 & 200 & 92 \\
\hline 30 & S.N 30 & 1630 & 7.1 & 121 & 71 & 44 & 21 & 390 & 146 & 101 & 13 & 0.43 & 1060 & 320 & 115 \\
\hline 31 & S.N 31 & 2160 & 7.3 & 89 & 64 & 28 & 3 & 294 & 117 & 73 & 12 & 0.52 & 1404 & 288 & 85 \\
\hline 32 & S.N 32 & 1940 & 7.2 & 93 & 64 & 22 & 2 & 343 & 123 & 33 & 15 & 0.48 & 1261 & 288 & 102 \\
\hline 33 & S.N 33 & 1720 & 7.1 & 101 & 59 & 27 & 3 & 338 & 121 & 41 & 20 & 0.39 & 1118 & 264 & 102 \\
\hline 34 & S.N 34 & 1960 & 6.9 & 69 & 56 & 25 & 12 & 205 & 62 & 129 & 18 & 0.45 & 1274 & 250 & 120 \\
\hline 35 & S.N 35 & 1940 & 7.1 & 83 & 81 & 45 & 45 & 370 & 129 & 115 & 14 & 0.40 & 1261 & 360 & 118 \\
\hline 36 & S.N 36 & 1660 & 6.7 & 77 & 97 & 86 & 32 & 393 & 154 & 161 & 13 & 0.38 & 1079 & 430 & 101 \\
\hline 37 & S.N 37 & 1850 & 6.8 & 79 & 58 & 45 & 16 & 307 & 109 & 77 & 12 & 0.48 & 1203 & 259 & 65 \\
\hline 38 & S.N 38 & 2060 & 7.5 & 109 & 82 & 39 & 25 & 376 & 161 & 97 & 12 & 0.44 & 1339 & 365 & 113 \\
\hline 39 & S.N 39 & 1880 & 7.1 & 91 & 101 & 45 & 41 & 433 & 170 & 101 & 13 & 0.42 & 1222 & 450 & 99 \\
\hline 40 & S.N 40 & 1520 & 7.2 & 95 & 85 & 26 & 36 & 349 & 120 & 135 & 14 & 0.34 & 988 & 380 & 86 \\
\hline
\end{tabular}


Groundwater occurs under water table conditions in the weathered zones of Papaghni and Chitravati group of rocks. The water present in the dug wells are mainly due to the numerous joints, fractures and fissures present in these rock types. The quartzites and the basal part of the massive limestone are good aquifers and the permanent water table in these is generally shallow. Water is alkaline in nature and suits both for irrigation and drinking purposes [25]. It is found that the groundwater in the Tummalapalle village is saline due to unhygienic conditions, since water found away from the village in surrounding area is generally sweet. The depth of water level is observed between 10 to $20 \mathrm{~m}$ in Vemula mandal [26].

\section{Hydrogeomorphology}

In the present study, the hydrogeomorphological mapping is carried out by using IRS P6 LISS-III satellite data. Based on genesis, lithology, physiography and landform characteristics three types of geomorphic units namely fluvial, denudational and structural are categorized covering these lithological formations (Figure 2). Under fluvial landforms valley and valley fill moderate are included in the study area. The denudational landforms include buried pediplain of shallow weathering, pediment, inselberg, and bazada. Structural Hills are included under structural landforms. The depth of the weathering and nature of soil cover plays a important role in the groundwater prospecting. Further, the pediplain is further sub-divided into pediplains with shallow and moderate weathering. Thus, based on the genesis, fifteen geomorphic units are delineated that are developed on seven lithological formations. Majority of the lineaments are in NE-SW and NW-SE directions.

The description of all these landforms developed on various lithological units viz., Fluvial landforms, Denuda-

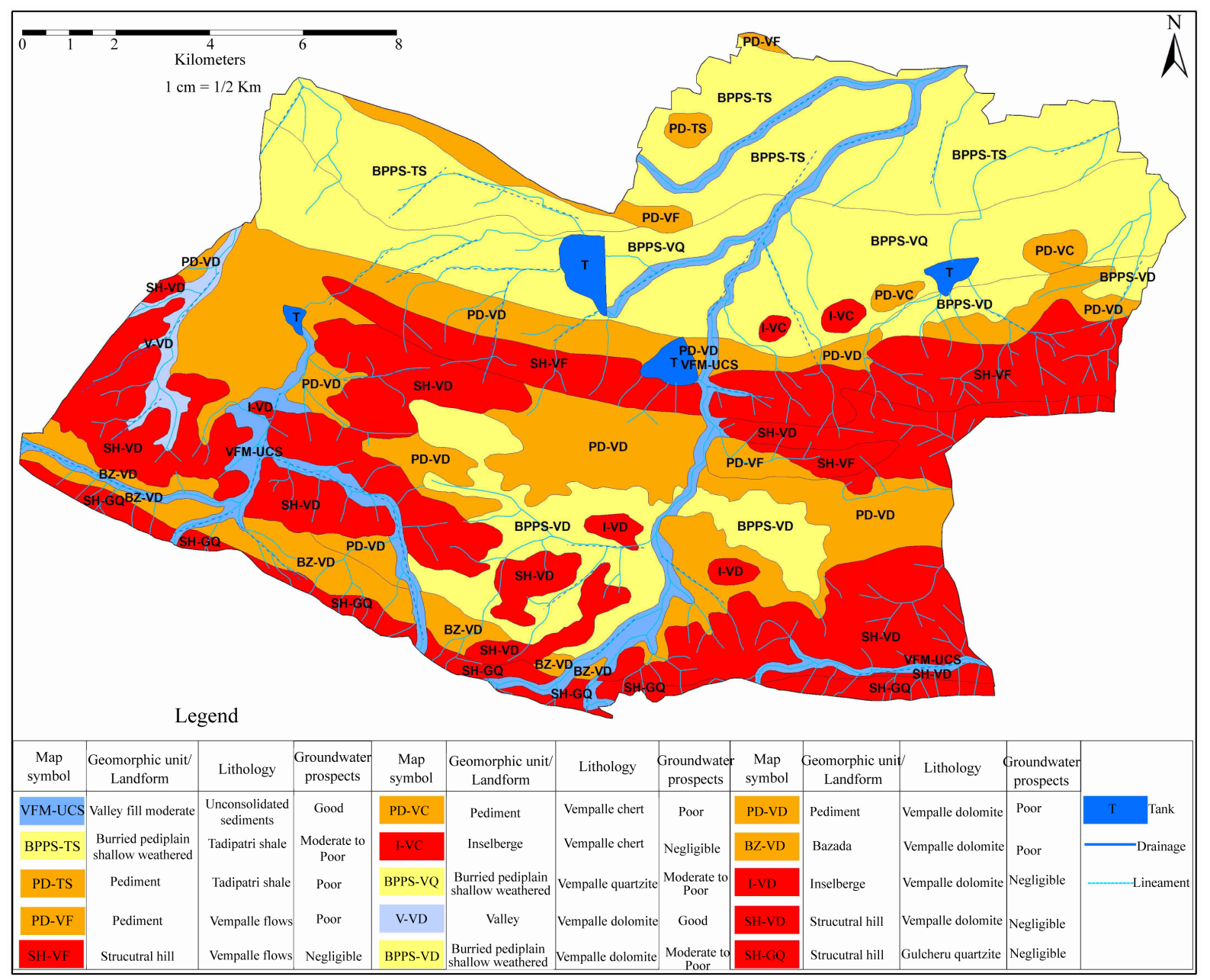

Figure 2. Hydrogeomorphology map of the study area. 
tional landforms and Structural landforms.

The fluvial landforms have been divided into two categories and they are Valley fill moderate (VFM-UCS) and Valley (V-VD). The valley fill are the valley filled with eroded materials. The thickness of the valley fill deposits varies from 10 to $20 \mathrm{~m}$. In the present study area, this unit is acting as good recharging zone and it is marked under moderate to good groundwater potential zone. Groundwater prospects in these valley fills zone are good to excellent. This is due to the topographical location at the bottom of the hill and geological composition consisting of highly porous materials. Subsurface water potential is also good to excellent in these valley fills [27]. The Valley (V-VD) is low laying depressions and negative landforms of varying size and shape occurring within the hills associated with stream. The valley bottoms are also discharge areas for ground water flowing from higher elevation catchments [28]. In general, the groundwater prospect in this landform is good. Similar studies have been performed by Binay Kumar and Uday Kumar in Lower Sanjai watershed area of Jharkhand for mapping of ground water prospects [29].

The Denudational landforms have been divided into four types viz., Shallow weathered buried pediplain, Pediment, Bezda and Inselberg. The Shallow weathered buried pediplainis a gently sloping flat and smooth surface of weathered Tadipatri shale, Vempalli dolomite and Vempalli quartzite with less than $10 \mathrm{~m}$ of weathering generally covered with black soil. Poor to moderate yields are expected in this unit. Moderate yields are expected along fracture/lineament. The quality of water is generally brackish in nature. Sree Devi et al. have noticed similar such observations in the Pageru river basin at Pullampally village in Cuddapah district of Andhra Pradesh [30]. The Pediment is a gently sloping smooth surface of erosional bedrock of Tadipatri shale, Vempalli chert, Vempalli dolomite and basic flows (Vempalli Flows) between hill and plain with thin veneer of detritus. In general, the groundwater prospects in this landform is poor. Further, this study has been supported by Suresh babu and Gautham [31]. The Bazada is a broad, continuous alluvial slope or gently inclined detrital surface of Vempalli dolomite extending along and from the base of mountain range. The groundwater prospects are poor in this landform. Similar findings have been observed in the Errakalava catchment area of Andhra Pradesh by Krishna et al. [32]. The Inselberg is a massive isolated hill of Vempalli chert and Vempalli dolomite abruptly rising above the surrounding plains. It forms a run-off zone without any significant recharge potential and groundwater prospects. Raghu and Mruthyunjaya Reddy have noticed similar phenomena in Akuledu Vanka Watershed area of Anantapur District in Andhra Pradesh [33].

The Structural Landforms consists of Structural Hill. These are linear to arcuate hills exhibiting definite trends composed of Vempalli dolomite, basic flows (Vempalli flows) and Gulcheru quartzite. This landform generally acts as a runoff zone and the groundwater prospects in these landforms are negligible. Moderate prospects are observed along valleys within the hills. It is noticed in Bata watershed of Sirmaur District of Himachal Pradesh employing the remote sensing data in conjunction with conventional methods to characterize the terrain and aquifer parameters [34].

\section{Groundwater Quality}

The quality of groundwater varies from place to place depending upon the geological formation, climate, drainage conditions, and pollution. The groundwater in archaean rocks is generally neutral to alkaline. The quality of groundwater occurring in Cuddapah and Kurnool formations is generally inferior in its quality [26]. Data interpretation involves comparison of water quality data, analysis of water quality trends, development of causeeffect relationships between water quality data and environmental data (geology, hydrology, land use, pollutant sources inventory), and judgement of the adequacy of water quality for various uses etc. For specific problems, and the evaluation of the environmental significance.

Scatter plots were drawn among TDS Vs EC; Na Vs K; Ca Vs Na; Mg Vs K; Cl vs Hardness; $\mathrm{CO}_{3}$ Vs Hardness; $\mathrm{CO}_{3} \mathrm{Vs} \mathrm{Cl} ; \mathrm{HCO}_{3} \mathrm{Vs}$ Hardness; $\mathrm{HCO}_{3} \mathrm{Vs} \mathrm{CO}_{3} ; \mathrm{HCO}_{3} \mathrm{Vs} \mathrm{Cl}$ in order to find out the relationship of chemical parameters of groundwater in the study area (Figure 3). Strong correlation exists among TDS Vs EC $\left(\mathrm{r}^{2}=\right.$ 1); $\mathrm{CO}_{3}$ Vs Hardness $\left(r^{2}=0.81\right) ; \mathrm{HCO}_{3}$ Vs Hardness $\left(\mathrm{r}^{2}=0.76\right) ; \mathrm{HCO}_{3} \mathrm{Vs} \mathrm{CO}_{3}\left(\mathrm{r}^{2}=0.94\right)$. From this study, it is clear that the correlation coefficient of various physico-chemical parameters are having significant relationship with each other parameter.

Conductivity is a function of temperature; it shows the types of ions present and the concentrations of these ions. The total dissolved solids, (TDS) is an index of conductivity, has a direct relationship to salinity and high total dissolved solids limits the suitability of water for potable use [35] [36]. The total dissolved solids are a 

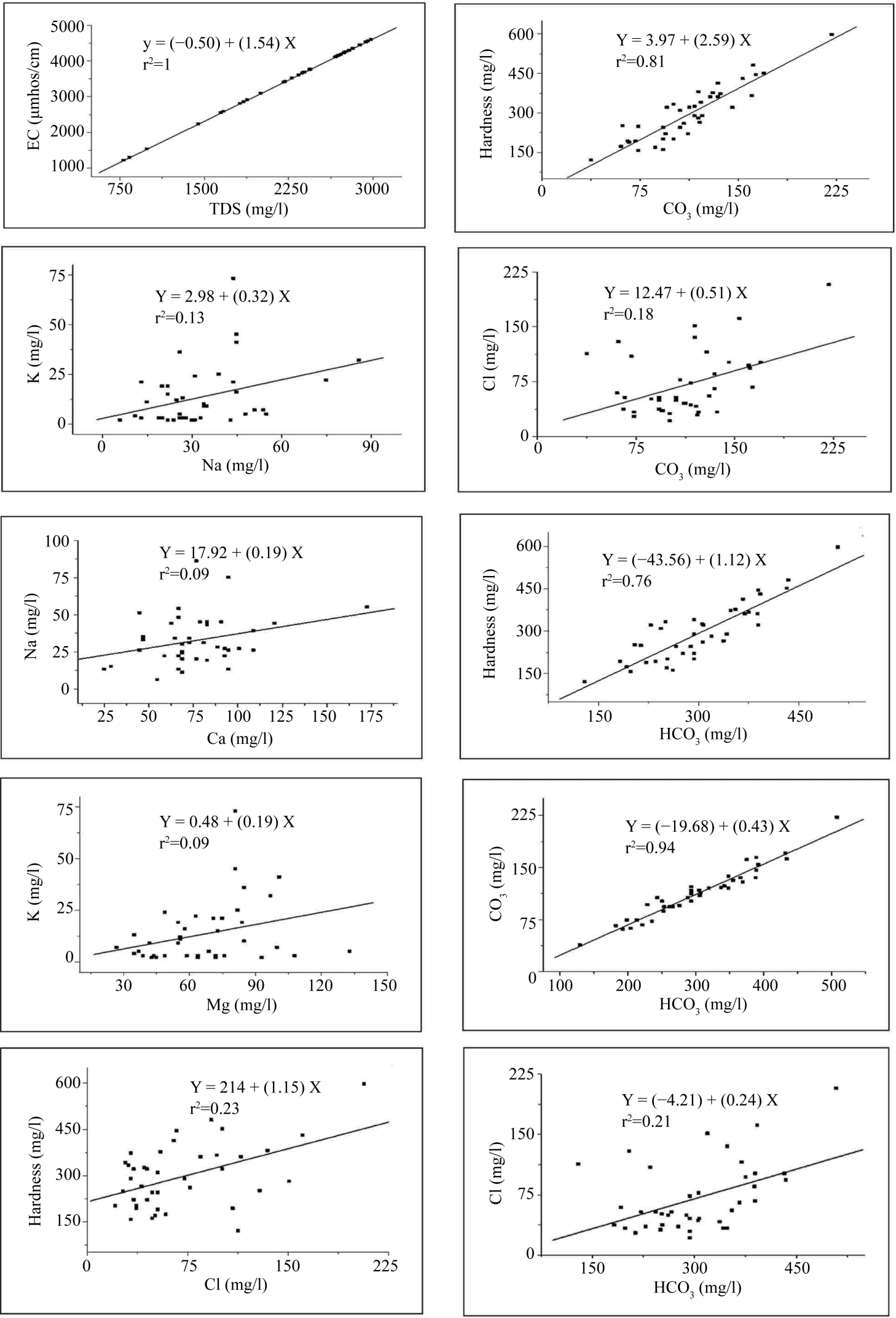

Figure 3. Scatter plots of various chemical parameters. 
measure of all dissolved substances in water. Primary source for the total dissolved solids are agricultural and residential runoff, leaching of soil contamination and point source water pollution discharged from industrial or domestic wastewater treatment plants [37]. Electrical conductivity (EC) and total dissolved Solids (TDS) are useful parameters for assessing the concentration of solid substances present in any sample of waste water. Figure 3 represents the linear regression of EC on TDS. The regression equation was $y=(-0.50)+(1.54) x$ and the $r^{2}$ is about 1 . The regression analysis has shown a strong significant linear relationship between electrical conductivity and total dissolved solids. Earlier studies have also reported such high degree of correlation between EC and TDS [38] [39].

Further, there is a positive correlation with carbonate and bicarbonate (Figure 3). In ground water, the hardness is formed mainly due to carbonate, bicarbonate, and chloride of $\mathrm{Ca}^{2+}$ and $\mathrm{Mg}^{2+}$ [40]. Total hardness of water is mainly governed by the cations of calcium and magnesium which largely combined with bicarbonates and carbonates (temporary hardness) and with sulphate, chlorides and other anions of minerals (permanent hardness). Higher values of hardness are due to the evaporation of water at higher temperatures during summer months, low water level and more anthropogenic activities [41] [42]. In the present study area, the source rocks are mainly responsible for contributing such large amounts of chemical elements. By observing these results, it can be concluded that the water quality parameters which are taken for study are satisfying the requirement for the use of various purposes like domestic, agricultural, industrial use.

The chemical parameters of groundwater which were taken for our study of Tummalapalle area are within the drinking water quality standards and are satisfying the requirement for various uses viz., domestic, agricultural, industrial purposes [43] [44]. The concentration of uranium in groundwater varies significantly from place to place are due to the heterogeneous distribution of uranium deposits in earth crust and geological formations surrounding Tummalapalle mining site. About $96 \%$ of the drinking water samples are having uranium concentration within the permissible limit (30 $\mu \mathrm{g} / \mathrm{l})$ as suggested by USEPA for drinking purpose [45].

\section{Conclusions}

The Remote Sensing and GIS techniques provided information pertaining to hydrogeomorphoic features was very useful in the understanding the nature and water potentiality of different landforms. The various landform units discussed are the result of different geomorphic processes. The study revealed the capability of remote sensing technology for preparing a hydrogeomorphological map. The study also shows the interrelationship of hydrogeomorphic units and other topographical feature and their importance in delineating the ground water potential zone in the terrain.

This study has highlighted the integrated modeling and analysis of various geospatial themes, like, topography, geomorphometry, geomorphology and hydrology in the GIS environment helped in reconstructing the hydrogeomorphological scenario of Tummalapalle area. The fluvial landforms good groundwater prospects while shallow weathered buried pediplain has moderate to poor groundwater prospects. Based on the physicochemical parameters ( $\mathrm{pH}, \mathrm{EC}$, total dissolved solids, carbonates, bicarbonates, alkalinity, chlorides, sulphates, fluoride, calcium, magnesium, sodium, and potassium) of groundwater in the vicinity of Tummalapalle area, it is considered that the that most of the groundwater samples can be used for irrigation and domestic purposes.

\section{Acknowledgements}

The authors are thankful to the Director General, Andhra Pradesh State Remote Sensing Applications Centre (APSRAC), Hyderabad for providing facilities to carry out thematic mapping work.

\section{References}

[1] Goel, P.K. (2000) Water Pollution-Causes, Effects and Control. New Age Int. (P) Ltd., New Delhi.

[2] Moharir, A., Ramteke, D.S., Moghe, C.A., Wate, S.R. and Sarin, R. (2002) Surface and Ground Water Quality Assessment in Bina Region. Indian Journal of Environmental Protection, 22, 961-969.

[3] Vasanthavigar, M., Srinivasamoorthy, K., Vijayaragavan, K., Ganthi, R., Chidambaram, S., Anandhan, P., Manivannan, R. and Vasudevan, S. (2010) Application of Water Quality Index for Groundwater Quality Assessment: Thirumanimuttar Sub-Basin, Tamilnadu, India. Environmental Monitoring and Assessment, 171, 595-609. http://dx.doi.org/10.1007/s10661-009-1302-1

[4] Elango, L., Suresh Kumar, S. and Rajmohan, N. (2003) Hydrochemical Studies of Ground Water in Chengalpet Region. 
Indian Journal of Environmental Protection, 6, 624-632.

[5] Khanam, Z. and Singh, V. (2014) Groundwater Quality Assessment near Polluted Canal Area in Kichha Town, Uttarakhand, India. International Journal of Recent Scientific Research, 5, 362-368.

[6] Sedhuraman, M., Revathy, S.S. and Suresh Babu, S. (2014) Integration of Geology and Geomorphology for Groundwater Assessment Using Remote Sensing and GIS Techniques. International Journal of Innovative Research in Science, Engineering and Technology, 3, 10203-10211.

[7] Das, S., Ed. (2008) Hydrogeological Research in India; Golden Jubilee Volume. Geological Society of India, 589.

[8] Kochtcheeva, L. and Sing, A. (1999) An Assessment of Risks and Threats to Human Health Associated with the Degradation of Ecosystems, United Nations Environment Programme (UNEP), 1-27.

[9] Pettorelli, N., Safi, W. and Turner, W. (2014) Satellite Remote Sensing, Biodiversity Research and Conservation of the Future. Philosophical Transactions of the Royal Society B, 369, 1-5.

[10] Prabhu, P., Balasubramanian, U. and Devendran, U. (2012) Preliminary Studies on Water Characteristics and Bacterial Population in Various Tissues of Catlacatla. International Journal of Pharmaceutical and Biological Archives, 3, 338341.

[11] Tewari, A., Dubey, A. and Trivedi, A. (2010) A Study on Physico-Chemical Characteristics of Ground Water Quality. Journal of Chemical and Pharmaceutical Research, 2, 510-518.

[12] Kuldip Singh, Er. and Yaseen Khan, M. (2014) Basic Necessity for the Survival of Humans: Drinking Water Quality in Rural India. Global Journal of Finance and Management, 6, 739-744.

[13] Thirumala, S. (2014) Groundwater Quality Analysis in Davangere City of Karnataka, India. International Journal of Innovative Research in Science, Engineering and Technology, 3, 12115-12123.

[14] Saraf, A.K. and Choudhury, P.R. (1998) Integrated Remote Sensing and GIS for Groundwater Exploration and Identification of Artificial Recharge Sites. International Journal of Remote Sensing, 19, 1825-1841. http://dx.doi.org/10.1080/014311698215018

[15] Gurugnanam, B., Prabhakharan, N., Suvetha, M., Vasudevan, S. and Gobu, B. (2008) Geographic Information Technologies for Hydro-Geomorphological Mapping in Parts of Vellar Basin, Central Tamilnadu. Journal of the Geological Society of India, 72, 471-478.

[16] Anji Reddy, M. (2002) Textbook of Remote Sensing and Geographical Information System. 2nd Edition, B.S. Publications, Hyderabad, 23-27.

[17] Gupta, R.P. (2003) Remote Sensing Geology. 2nd Edition, Springer Verlag, Berlin Heidelberg, 1-11. http://dx.doi.org/10.1007/978-3-662-05283-9

[18] Pandya, M.R., Singh, R.P., Chaudhri, K.N., Murali, K.R., Kinankumar, A.S., Dadhwal, V.K. and Parihar, J.S. (2007) Spectral Characteristics of Sensors Onboard IRS-1D and P6 Satellites: Estimation and Their Influence on Surface Reflectance and NDVI. Journal of the Indian Society of Remote Sensing, 35, 333-350. http://dx.doi.org/10.1007/BF02990789

[19] NRSA (National Remote Sensing Agency) (2008) Groundwater Prospects Mapping Using Remote Sensing and Geographic Information System. Rajiv Gandhi National Drinking Water Mission Project, Manual, 256.

[20] Lillisand, T.M., Keiffer, R.W. and Chapman, J.W. (2007) Remote Sensing and Image Interpretation. Sanat Printers, Haryana, 3-24.

[21] APHA (2005) Standard Methods for the Examination of Water and Wastewater. 21st Edition, American Public Health Association, Washington DC.

[22] Todd, D.K. and Mays, L.W. (2005) Groundwater Hydrology. 3rd Edition, Wiley, Hoboken, 656.

[23] Basu, H. (2007) Geological and Geochemical Aspects of the Gulcheru Formation in the Southwestern Margin of the Cuddapah Basin and Its Potentiality for Uranium Mineralisation. Journal of the Geological Society of India, 70, 686688.

[24] Basu, H., Mahendra Kumar, K., Paneerselvam, S. and Chaki, A. (2009) Study of Provenance Characteristics and Depositional History on the Basis of U, Th and K Abundances in the Gulcheru Formation, Cuddapah Basin in Tummalapalle-Somalollapalle Areas, Cuddapah-Anantapur Districts, Andhra Pradesh. Journal of the Geological Society of India, 74, 318-328. http://dx.doi.org/10.1007/s12594-009-0136-3

[25] GSI (Geological Survey of India) (2001) District Resource Map. Cuddapah District, Andhra Pradesh.

[26] CGWB (Central Ground Water Board) (2007) Ground Water Information. Kadapa District, Andhra Pradesh, 45.

[27] Krishnamurthy, J. and Srinivas, G. (1995) Role of Geological and Geomorphological Factors in Ground Water Exploration: A Study Using IRS LISS Data. International Journal of Remote Sensing, 16, 2925-2618.

http://dx.doi.org/10.1080/01431169508954579 
[28] Haldar, D., Sehgal, V.K., Kumar, G. and Sundara Sarma, K.S. (2011) Evaluation of Ground Water and Land Resources in Relation to Landforms in Alwar District (Rajasthan): A Remote Sensing Based Approach. Archives of Environmental Science, 5, 37-45.

[29] Kumar, B. and Kumar, U. (2010) Integrated Approach Using RS and GIS Techniques for Mapping of Ground Water Prospects in Lower Sanjai Watershed, Jharkhand. International Journal of Geomatics and Geosciences, 1, 587-598.

[30] Sree Devi, P., Srinivasulu, S. and Raju, K.K. (2001) Hydrogeomorphological and Groundwater Prospects of the Pageru River Basin by Using Remote Sensing Data. Environmental Geology, 40, 1088-1094. http://dx.doi.org/10.1007/s002540100295

[31] Suresh Babu, G. and Gautham, G. (2014) Integrated Study Using Remote Sensing and GIS for Ground Water Prospect Zones and Management in Mylavaram Mandal, YSR Kadapa, Andhra Pradesh. International Journal of Environmental Research and Development, 4, 411-416.

[32] Krishna, N.D.R., Krishna Murthy, Y.V.N., Rao, B.S.P. and Srinivas, C.V. (2000) Geoinformatics for Ecological-Economic Zoning towards Land Use Planning in Yerrakalava Catchment, Andhra Pradesh. Agropedology, 10, 116-131.

[33] Raghu, V. and Reddy, K.M. (2011) Hydrogeomorphological Mapping at Village Level Using High Resolution Satellite Data and Impact Analysis of Check Dams in Part of Akuledu Vanka Watershed, Anantapur District, Andhra Pradesh. Journal of Indian Geophysical Union, 15, 1-8.

[34] Kishore, S., Srivastav, S.K. and Jugran, D.K. (2006) Ground Water Prospects Zonation Using Remote Sensing and Gis-A Case Study of Bata Watershed, Sirmaur District, H.P. Symposium of ISPRS Commission IV, Goa, 30 September 2006, 36.

[35] Davis, S.N. and DeWiest, R.J.M. (1991) Hydrogeology. Krieger Publishing Company, Malabar, Florida, 463.

[36] Hem, J.D. (1985) Study and Interpretation of Chemical Characteristics of Natural Water. U.S.G.S. Water Supply Paper 2254, 263.

[37] Miroslav, R. and Vladimir, N.B. (1999) Practical Environmental Analysis. Royal Society of Chemistry, UK, 152-175.

[38] Bajpayee, S., Das, R., Ruj, B., Adhikari, K. and Chatterjee, P.K. (2012) Assessment by Multivariate Statistical Analysis of Ground Water Geochemical Data of Bankura, India. International Journal of Environmental Sciences, 3, 870880.

[39] Uwidia, I.E. and Ukulu, H.S. (2013) Studies on Electrical Conductivity and Total Dissolved Solids Concentration in Raw Domestic Wastewater Obtained from an Estate in Warri, Nigeria. Greener Journal of Physical Sciences, 3, 110114.

[40] Alagumuthu, G. and Rajan, M. (2008) Monitoring of Fluoride Concentration in Ground Water of Kadayam Block of Tirunelveli District, India: Correlation with Physico-Chemical Parameters. Rasayan Journal of Chemistry, 1, 920-928.

[41] Singh, M., Lodha, P. and Singh, G.P. (2010) Seasonal Diatom Variations with Reference to Physico-Chemical Properties of Water of Mansagar Lake of Jaipur, Rajasthan. Research Journal of Agricultural Sciences, 1, 451-457.

[42] Khan, R.F., Jadhav, M.J. and Ustad, I.R. (2012) Physicochemical Analysis of Triveni Lake Water of Amravati District in (MS) India. Bioscience Discovery, 3, 64-66.

[43] Reddy, P.G.P. and Reddy, G.V.S. (2011) Physico-Chemical Analysis of Surface and Groundwater of Selective Areas of UCIL Thummalapalli Project, YSR (Kadapa), Andhra Pradesh, India. African Journal of Scientific Research, 3, 164-178.

[44] Chandra Sekhar Reddy, L., Deshpande, S.M., Ramana Reddy, K.V. and Aher, K.R. (2012) Hydro Geochemical Processes in the Groundwater Environment of Vemula Area, Kadapa District, South India. International Journal of Recent Trends in Science and Technology, 3, 18-24.

[45] Yasovardhan, N., Basha, A.M., Satyanarayana, S.V., Reddy, G.V.S., Prasad, K.V., Savithri, P.P. and Kumar, P.P. (2013) Seasonal Assessment of Natural Uranium in Drinking Water around Tummalapalle Uranium Mining Site, Kadapa District, India. International Journal of Recent Scientific Research, 4, 1406-1409. 